\title{
Identification of Domestic Liquid Waste Sanitation Conditions in an Effort the Improvement of Sanitation in Karanganyar
}

\author{
Nining Indrastuti ${ }^{1}{ }^{1}$ Ashadi $^{2}$, Prabang Setyono ${ }^{2}$, Sunarto $^{2}$ \\ ${ }^{1}$ Graduate Students, ${ }^{2}$ Lecturer Postgraduate of Universitas Sebelas Maret Surakarta \\ Jalan Ir. Sutami 36 A, Surakarta, 57126, Tel. +62271-646994, Fax. +62271-646655, Indonesia \\ ${ }^{1}$ Email: niningindrastuti@gmail.com
}

\begin{abstract}
Domestic liquid waste sanitation conditions in Karanganyar is the circumstances or description of the environment sewage from household activity results in particular black water located in Karanganyar. Identification purposes is to provide information about the condition of domestic waste sanitation in Karanganyar, which is necessary to address insecurity about sanitation. Karanganyar is a Regency which have abundant areas prone to sanitation. Karanganyar has 177 villages with poor sanitation conditions following six villages at risk is very high, 77 Villages at high risk, medium risk and the village of 5440 Villages are less risky. Sanitary conditions are influenced by various factors, among others, the type of means of sanitation and the quantity of domestic waste generated per person in district at Karanganyar. Type of sanitation facility that is in the community's variegated Karanganyar Regency such as cubluk, jumbleng, septic latrines with goose neck and WC sit with septic tanks. Socio-economic conditions determine the type of selected community sanitation. According to the BPS, the number of poor households in Karanganyar of 5 rating is the largest Sub Gondangrejo, Mojogedang, Jumapolo, Kebakkramat and Karanganyar. From the results of the sample population of 285 quisioner the respondent inhabitants in Karanganyar earned a percentage of population in a town is not served by sanitation more than $60 \%$ as follows Jenawi $94.1 \%$, Karangpandan 78\%, Jumapolo 75.1\%, Karanganyar 70.8\%, Jatiyoso 70\%, Mojogedang 65.4\%, Jumantono 63\%, Kebakkramat 62.5\% dan Ngargoyoso $61.2 \%$. The results of the identification that Kecamatan prone concluded that sanitation, thus requiring handling domestic waste processing to improve sanitation in Karanganyar Regency. The selected processing system and is expected to effectively, efficiently and in accordance with the socio-economic conditions of society as well as the sustainable.
\end{abstract}

Keywords: Black water, Domestic liquid waste, Sanitary conditions, Sanitation services, The type of means of sanitation

\section{INTRODUCTION}

Sanitation sector is one of public services that have a relation with poverty. Inadequate sanitary conditions would be badly health conditions and environment especially in the area of settlements, slum and poor in Karanganyar. Indonesia is one of countries with a degree of ownership of the network system of waste water (sewerage) lowest in Asia. Less than 10 cities in Indonesia that has waste water network system with service levels around $1.3 \%$ of the total population.

The main causes of poor sanitation conditions in Indonesia are weak sanitation development planning: not integrated, wrong target, not according to needs and not sustainable, as well as the lack of public attention on the behavior of living clean and healthy. The problem of sanitation in Karanganyar is a responsibility of Governments and the role of community in handling, for the realization of good sanitation, adequate and proper would not be achieved in the absence of cooperation between the Government and people especially in the Karanganyar. The availability of facilities and information systems concerning conditions of sanitation is a right of citizens especially in the Karanganyar. In addition public awareness for clean living and well behaved (PHBS) is indispensable in order for the creation of conditions for good and decent sanitation.
Karanganyar is a Regency of which many have areas prone to sanitation. Karanganyar has 177 villages with poor sanitation conditions following six villages at risk is very high, 77 Villages at high risk, medium risk and the village of 5440 Villages are less at risk.

\section{MATERIALS AND METHODS}

Research methods was spread the quisioner to the respondent as much as 285 samples of populations from the Karanganyar people spread across several districts and analyze primary data from BPS (Central Bureau of statistics), health services, BLH (the Environmental Agency) and DPUPR (Department of public works and Spatial).

\section{RESULTS AND DISCUSSION}

Sanitary condition of domestic waste in Karanganyar is description of environment sewage from household activity results in particular black water that is affected by the type of means of sanitation and the quantity of domestic waste generated everyone is \pm 90 litres/Pax/day. Sanitation sector is one of public service that has the link closely with the poverty that give bad impact towards health and environmental conditions especially in the area of settlements, slum and poor. 
Sanitary means of domestic waste in Karanganyar consists of various types of sanitary and strongly influenced by socio-economic conditions of communities in Karanganyar. Socio-economic conditions determine the type of selected community sanitation. The inability of great poverty or economic impact of sanitary conditions of domestic waste in Karanganyar. The following is the number of poor households to every town in Karanganyar, of the total number of households per subdistrict. The number of poor households per sub district can be seen in the table 1.

The means of Community Sanitation in Karanganyar in each household uses on site sanitation (place) with kind of sanitation be privy. Every household in Karanganyar means there is a wide range of sanitasinya that uses the toilets healthy (latrines with goose neck and septic tanks), the toilets are not healthy (simple latrines, cubluk, jumbleng/cemplong) and others do not have the toilets. Who do not have latrines are usually those chapters (Defecate) on the River, gardens and take in neighbors or other household. The following is a table of the number of households that have had Privy is healthy, has a toilet but not healthy and the toilets got totally refuses in each subdistrict in Karanganyar Regency.
Table 1. The number of poor households Karanganyar regency (2012).

\begin{tabular}{llll}
\hline No. & Subdistrict & $\begin{array}{l}\text { The Number of } \\
\text { Households (KK) }\end{array}$ & $\begin{array}{l}\text { The Number of } \\
\text { Poor Households } \\
\text { (KK) }\end{array}$ \\
\hline 1 & Jatipuro & 8456 & 1.691 \\
2 & Jatiyoso & 8712 & 1.022 \\
3 & Jumapolo & 10.084 & 2.763 \\
4 & Jumantono & 12.179 & 2.323 \\
5 & Matesih & 9861 & 732 \\
6 & Tawangmangu & 10.497 & 387 \\
7 & Ngargoyoso & 7.692 & 1.381 \\
8 & Karangpandan & 9.318 & 1.430 \\
9 & Karanganyar & 17.873 & 2.517 \\
10 & Tasikmadu & 14.027 & 1.498 \\
11 & Jaten & 18.889 & 2.126 \\
12 & Colomadu & 15.955 & 1.132 \\
13 & Gondangrejo & 18.194 & 5488 \\
14 & Kebakkramat & 14.262 & 2.700 \\
15 & Mojogedang & 13.670 & 3.992 \\
16 & Kerjo & 8.339 & 1.756 \\
17 & Jenawi & 6.076 & 1.052 \\
TOTAL & $\mathbf{2 0 4 . 8 1 3}$ & $\mathbf{3 3 . 9 5 0}$ \\
\hline
\end{tabular}

Source: Central Bureau of statistics Government Karanganyar (2012).

Table 2. The number of households and facilities place defecation residents in Karanganyar regency.

\begin{tabular}{lllll}
\hline & No. & The Toilets Healthy $($ KK) & The Toilets Are Not Healthy (KK) & $\begin{array}{l}\text { Do Not Have Latrines } \\
\text { (KK) }\end{array}$ \\
\hline 1 & Jatipuro & 8.379 & 1.815 & 423 \\
2 & Jatiyoso & 5.669 & 2.731 & 3.968 \\
3 & Jumapolo & 8.304 & 855 & 5.385 \\
4 & Jumantono & 8.553 & 1.026 & 4.361 \\
5 & Matesih & 10.576 & 67 & 544 \\
6 & Tawangmangu & 11.082 & 2.803 & 1.650 \\
7 & Ngargoyoso & 6.309 & 625 & 3.236 \\
8 & Karangpandan & 7.211 & 144 & 5.478 \\
9 & Karanganyar & 13.355 & 790 & 8.661 \\
10 & Tasikmadu & 12.426 & 191 & 5.928 \\
11 & Jaten & 17.683 & 58 & 3.924 \\
12 & Colomadu & 14.867 & 1.413 & 3.586 \\
13 & Gondangrejo & 12.863 & 1.261 & 6.277 \\
14 & Kebakkramat & 9.893 & 726 & 5.456 \\
15 & Mojogedang & 10.861 & 2.859 & 4.240 \\
16 & Kerjo & 8.199 & 2.243 & 373 \\
17 & Jenawi & 433 & 5.415 & 1.544 \\
TOTAL & $\mathbf{1 6 6 . 6 6 3}$ & $\mathbf{2 5 . 0 2 2}$ & $\mathbf{6 5 . 0 4 4}$ \\
\hline
\end{tabular}

Source: Health office karanganyar regency (2012).

\section{Description:}

-Privy latrines with healthy: the neck of goose and septic tanks

-The toilets are not healthy: simple latrines, cubluk, jumbleng/cemplong

-BABS: Defecation Carelessly (rivers, irrigation canals, gardens, fields, etc.).
The quantity of domestic waste is calculated based on the number of people in each subdistrict in Karanganyar in 2016 and large waste is produced per person per day. Standard SNI 19-3964-1994 in litres 22.5 litres/org/day or in $\mathrm{kg}$ of $0.4-0.5 \mathrm{~kg} / \mathrm{Pax} /$ day. 
Table 3. The quantity of domestic waste and \% of sanitation services (2018).

\begin{tabular}{llllll}
\hline \multirow{2}{*}{ No. } & Subdistrict & \multicolumn{2}{c}{ The Volume of Waste } & Layanan $(\%)$ & Not Served $(\boldsymbol{\%})$ \\
\cline { 3 - 5 } & & Liters/Org/Day & Kg/Org/Day & \\
\hline 1 & Jatipuro & $105.812,5$ & $21.162,5$ & 73,3 & 26,7 \\
2 & Jatiyoso & $108.900,0$ & $21.780,0$ & 30 & 70,0 \\
3 & Jumapolo & $135.050,0$ & $27.010,0$ & 24,9 & 75,1 \\
4 & Jumantono & $152.237,5$ & $30,447,5$ & 37 & 63 \\
5 & Matesih & $123.262,5$ & $24.652,5$ & 5,9 & 40,2 \\
6 & Tawangmangu & $131.212,5$ & $26.242,5$ & 61,2 \\
7 & Ngargoyoso & $96.150,0$ & $19.230,0$ & 59,8 & 78,0 \\
8 & Karangpandan & $116.475,0$ & $23.295,0$ & 38,8 & 70,8 \\
9 & Karanganyar & $223.412,5$ & $44.682,5$ & 22,0 & 49,2 \\
10 & Tasikmadu & $175.337,5$ & $35.067,5$ & 29,2 & 22,5 \\
11 & Jaten & $236.112,5$ & $47.225,5$ & 50,8 & 77,5 \\
12 & Colomadu & $199.437,5$ & $39.887,5$ & 66,4 & 33,6 \\
13 & Gondangrejo & $227.425,0$ & $45.485,0$ & 41,75 & 58,25 \\
14 & Kebakkramat & $178.275,0$ & $35.655,0$ & 37,5 & 62,5 \\
15 & Mojogedang & $170.875,0$ & $34.175,0$ & 34,6 & 65,4 \\
16 & Kerjo & $104.237,5$ & $20.847,5$ & 75,9 & 24,1 \\
17 & Jenawi & $75.950,0$ & $15.190,0$ & 5,9 & 94,1
\end{tabular}

Source: analysis results (2018).

\section{CONCLUSIONS}

Sanitation conditions are influenced by various factors including the type of sanitation facilities and the quantity of domestic waste produced by each person in the sub-district in Karanganyar. Based on the results of the correspondent questionnaire, it is known that the types of sanitation facilities in Karanganyar are diverse, such as cubluk, jumbleng, septic latrines with goose necks and sitting toilets with septic tanks. Determining the type of sanitation is influenced by socio-economic conditions determining the type of sanitation chosen by the community. Based on BPS data, the number of poor households in Karanganyar from the 5 largest ranks is Gondangrejo District, Mojogedang, Jumapolo, Kebakkramat and Karanganyar.

The results of the questionnaire 285 samples of the population in Karanganyar obtained the percentage of the population in a sub-district that was not served by sanitation more than $60 \%$ as follows: Jenawi $94.1 \%$, Karangpandan $78 \%$, Jumapolo $75.1 \%$, Karanganyar $70.8 \%$, Jatiyoso $70 \%$, Mojogedang $65.4 \%$, Jumantono 63\%, Kebakkramat $62.5 \%$ and Ngargoyoso $61.2 \%$. The identification results conclude that the Districts of Jenawi, Karangpandan, Jumapolo, Karanganyar, Jatiyoso, Mojogedang, Jumantono, Kebakkramat and Ngargoyoso are sub-districts that are prone to sanitation, thus requiring domestic waste treatment to improve sanitation in Karanganyar.

The domestic waste treatment system, especially black water which is chosen, is expected to be effective, efficient and in accordance with the socioeconomic conditions of the community and sustainable.
Sanitation development planning is expected to be integrated, on target, according to needs and sustainable and community participation is needed to implement Clean and Healthy Life Behaviors (PHBS) in their environment.

\section{REFERENCES}

Azwar, A. (1995). Introduction to Environmental Health Sciences. Jakarta: PT. Mutiara Sumber Widya.

Bui X. T. H. N. P. Dan., 2013. Study on treatment performance of low cost membrane based septic tank at various fluxes. International Journal of Waste Resource (IJWR).

Chandra, B. (2007). Introduction to Environmental Health. Jakarta: EGC.

Djajadiningrat, A., Prof. Dr. Ir. KRT. Environmental Pollution, Environmental Management and Handling Technology. Directorate of Environmental Technology Deputy of TIEML BPPT, Jakarta, 2000.

Karanganyar Central Statistics Agency. 2012. District in numbers. Sanitation Data from Karanganyar District Health Office

Karanganyar Regency Regional Regulation. 2012. Explanation of Karanganyar Regency Local Regulation Number 10 of 2012Law No. 32 of 2009 concerning the Environment.

Ruslan R. M and and Soedjono, E. S. (2008). Management of Tanjungpinang City Sanitation Sector Regarding Residents' Expectations. digilib.its.ac.id/public/ITS-Master-10755Paper.pdf

Salvato, J. A. (1982). Environmental Engineering And Sanitation Third Edition. John Wiley and Sons. New York.

Sanitarno, I. (2008). International Journal of Sanitary Engineering Research.

Sugandhy, A and Hakim, R. (2007). Basic Principles of Environmentally Sustainable Sustainable Development Policy. Jakarta: Bumi Aksara.

The White Book of Sanitation in Karanganyar Regency. 2012. Chapter I, II, III and V. Karanganyar Regency. 
THIIS PAGE INTENTIONALLY LEIT BLANK 